\title{
Determining the Separation Performance of the Knelson Concentrator
}

\author{
Ozcan ONEY'), Selcuk SAMANLI ${ }^{2)}$
}

\footnotetext{
1) Usak University, Department of Mining Engineering, Usak, Turkey; email: ozcan.oney@usak.edu.tr

2) Usak University, Department of Mining Engineering, Usak, Turkey; email: selcuk.samanli@usak.edu.tr
}

http://doi.org/10.29227/IM-2020-01-14

Submission date: 17-12-2019 | Review date: 15-02-2020

\section{Abstract}

This study was aimed at determining the separation performance of the Knelson concentrator in Zonguldak fine coal (-1+0.15 mm). The experiments were carried out in the Knelson concentrator under the following optimal parameters determined in previous studies; water flow rate of $3.14 \mathrm{~L} / \mathrm{min}$., bowl speed of $459 \mathrm{rpm}$, solids ratio of $23.87 \%$, and feed flow rate of $1.50 \mathrm{~L} / \mathrm{min}$. A series of tests were conducted at optimal test parameters to obtain enough samples for float and sink analysis. Clean coal and tailing products were subjected to float and sink analysis. Based on this analysis, partition curve for coal cleaning process was generated. The cut-point of the separation was obtained at the specific gravity of $1.72\left[\mathrm{~g} / \mathrm{cm}^{3}\right]$. The probable error (Ep) value, which signifies the efficiency of the process, was calculated as 0.11 These results indicated that Knelson concentrator is very effective in separating fine coal.

Keywords: knelson concentrator, fine coal, separation performance, float and sink analysis, partition curve

\section{Introduction}

A typical coal preparation plant may incorporate four processing flow sheets for treating run-of-mine (ROM) feed (Lutrell et al. 2000). The coarse $(+12 \mathrm{~mm})$ and intermediate $(-12+1 \mathrm{~mm})$ size particles are normally treated using heavy medium baths and jigs and heavy medium cyclones, respectively. While screens are used to dewater the coarse products, centrifugal dryers are employed to dewater smaller coals. Water-based density separators like spirals and water-only cyclones are generally utilized for upgrading fine coal $(-1+$ $0.150 \mathrm{~mm}$ ). Its performance efficiency is lower than those obtained by heavy medium-based concentrators. Ultrafine coal $(-0.150 \mathrm{~mm})$ is cleaned using flotation (column flotation or conventional flotation) or discarded to waste pond (Zhang, 2008). These process flow circuits may differ based on various product specifications demanded by the coal market (Meyer and Craig, 2011). Fine coal separators including coal spiral separator, fine coal heavy medium cyclone, enhanced gravity separator, teetered bed separator, and reflux classifier have shown a marked improvement in recent years (Honaker and Forest, 2003; Zhang et al. 2014).

Being developed and commercialized in the 1990's, enhanced gravity separators (EGS) are gravity concentrators operating at a centrifugal force to increase the settling rate of particles by rotating the separating vessel (Majumder and Barnwall, 2008). The EGS units work based on conventional density-based separation principles and an enhanced gravity field provided by a mechanical spinning action (Honaker and Ozsever, 2000). Today, it is possible to find a new generation of centrifugal enhanced gravity separators in the market for cleaning fine coals. Falcon Concentrator, Kelsey Jig, Knelson Concentrator, and Mozley Multi-Gravity Separator are among commercial units (Lutrell et al. 1995). The advancements in enhanced centrifugal gravity separators have led to improve treatment capabilities of gravity separating equipment for fine coal. Being one of the enhanced gravity separators, the
Knelson concentrator is basically a hindered settling device, related to a hydrosizer, using centrifugal force instead of the force of gravity (Tao et al. 2006; Uslu et al. 2012).

\section{Knelson concentrator}

Being an EGS technology, the Knelson concentrator operates based on teeter-bed principles in a centrifugal field to separate fine particles (Honaker et. al. 2005) Fig. 1 shows schematic illustration of a Knelson concentrator.

This concentrator is a vertical axis bowl-type centrifugal concentrator and utilizes a fluidized bed to perform its concentrating duty. After it was first introduced as a semi-batch unit in 1982, it has been subjected to several iterations of design, resulting in the invention of a continuous discharge machine (McLeavy et al. 2001; Majumder and Barnwall, 2006). The models are basically composed of a conical inner shell and several parallel "vee" shaped riffles, bolted to a rotating outer shell (Majumder and Barnwall, 2006).

A separation process is realized as follows; feed is introduced in the form of slurry at the bottom of the unit through a central tube. A theoretical centrifugal force of around 60G leads the feed solids to fill the inter-riffle spaces completely. After solids fill in these spaces, the further feed starts to introduce in the sorting stages. At this point, heavy minerals replace with light minerals and are trapped in the inter-riffle spaces; on the other hand, the lighter counterparts are carried by water toward the top of the unit. Thus, fluidized water is given through the multiple fluidization holes in the inner chamber in order to keep the bed of heavy minerals (Honaker and Ozsever, 2000). This fluidization water force is expected to be strong enough to prevent severe compaction of the heavy mineral bed due to the strong centrifugal force (Banisi, 1990; Majumder and Barnwall, 2006). The concentration mechanism of a Knelson concentrator may thus be attached to a hindered settling classifier (Burt 1992; Laplante 1993; Majumder and Barnwall, 2006). 


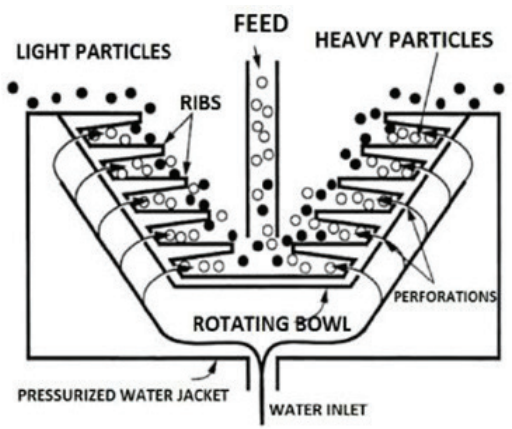

Fig. 1. Schematic illustration of a Knelson concentrator (Kawatra and Eisele, 2001) Rys. 1. Schemat separatora Knelson (Kawatra i Eisele, 2001)

Tab. 1. Size distribution and ash content of Amasra fine coal Tab. 1. Rozkład wielkości ziarna dla popiołu z drobnouziarnionego węgla z Amasry

\begin{tabular}{|c|c|c|c|c|}
\hline \multirow{2}{*}{$\begin{array}{c}\text { Size fraction } \\
(\mathbf{m m})\end{array}$} & \multirow{2}{*}{$\begin{array}{c}\text { Weight } \\
\mathbf{( \% )}\end{array}$} & \multirow{2}{*}{$\begin{array}{c}\text { Ash } \\
\mathbf{( \% )}\end{array}$} & \multicolumn{2}{|c|}{ Cumulative undersize } \\
\cline { 4 - 5 } & & & $\mathbf{A s h}$ & Weight \\
\cline { 4 - 5 } & & 19.65 & 24.78 & 100.00 \\
\hline $1.00-0.850$ & 11.31 & 20.38 & 25.43 & 88.69 \\
\hline $0.850-0.600$ & 20.95 & 22.84 & 26.99 & 67.74 \\
\hline $0.600-0.425$ & 30.53 & 24.60 & 30.39 & 37.21 \\
\hline $0.425-0.300$ & 17.63 & 34.17 & 35.61 & 19.58 \\
\hline $0.300-0.212$ & 15.87 & 31.78 & 41.78 & 3.71 \\
\hline $0.212-0.150$ & 3.71 & 41.78 & \\
\hline Total & $\mathbf{1 0 0 . 0 0}$ & $\mathbf{2 4 . 7 8}$ & & \\
\hline
\end{tabular}

\section{Material and Method}

The raw slurry sample was obtained from the flotation feeding unit of Amasra Mine Coal Washing Plant. This sample was screened from $0.150 \mathrm{~mm}$ and divided into two parts; fine coal $(-1+0.150 \mathrm{~mm})$ and ultrafine coal $(-0.150 \mathrm{~mm})$. Table 1 shows screen analysis of fine coal enriched with Knelson concentrator.

The ash content of the feed varied from $19.65 \%$ to $41.78 \%$ for each size fraction with total ash content of $24.78 \%$. Ash content increased rapidly with decreasing particle size. The finest fraction of the fine coal has more ash content.

Feed sample was subjected to float and sink analysis. Table 2 shows float and sink analysis results of the feed material is given in.

The washability curves were plotted as cumulative float curve, cumulative sink curve \pm 0.1 relative density curve and density and ash characteristic curve (Figure 2).

Several tests were performed with a laboratory type KC- MD3 Knelson concentrator to obtain sufficient overflow (clean coal) and underflow (waste material) products for float and sink analysis. For this purpose, the experiments were carried out at optimal operating conditions determined in previous studies (Oney et al. article in press; http://dx.doi. org/10.1080/1939 2699.2017.1397641). The results of this study revealed that the optimal predicted values were obtained at $79.33 \% \gamma_{C}, 12.52 \% 9$ and $91.95 \% \varepsilon$ in the operating parameters of the fluidization water flow rate, bowl speed, solids ratio and feed flow rate by using response surface methodology. It should be noted that these parameters significantly affect performance of Knelson concentrator. In the tests, a laboratory type Knelson unit, a slurry feed unit with a stirrer, and a peristaltic pump were used. Concentration of feed sol- ids was maintained at $23.87 \%$ by weight. Fluidization water flow rate was kept constant at $3.14 \mathrm{~L} / \mathrm{min}$. and the speed of the bowl was adjusted to $459 \mathrm{rpm}$. The slurry was agitated continuously so that the solids were kept in suspension and the material was fed regularly. Flow rate of the peristaltic pump was adjusted to $1.50 \mathrm{~L} / \mathrm{min}$.

The clean coal and waste material were subjected to the float and sink analysis. For this purpose, liquids of different specific gravity varying from 1.3 to 1.9 with typical step intervals of 0.1 were prepared using $\mathrm{ZnCl}_{2}$. Firstly, the sample was placed in the liquid with lowest specific gravity. The fraction higher than the liquid floats and heavier part sinks. Sink fraction refers to the portion floating with a particular specific gravity and the portion sinking. Then, the sinks were placed with next higher specific gravity so that the float and sink fractions were separated. Weight and ash content of sink and float products were gathered, dried, and examined at each bath.

\section{Results and Discussion}

It was found based on the results of float and sink analysis that the clean coal had a total ash content of $12.51 \%$ (Table 3 and Figure 3).

Based on the Table 3 it was observed that while the weight content of the lightest coal fraction was $33.67 \%$, its ash content was $3.93 \%$. This may be associated with being vitrain. Clean coal is mainly floated at a specific gravity between $1.30-1.50$. The cumulative ash content of clean coal at the density of 1.50 was $7.16 \%$ and its total weight was $87.10 \%$. Table 3 also shows that the amount of clean coal material at the specific gravities between 1.5 and 1.9 was very low which corresponded to a small amount of locked particles. 
Tab. 2. Float-sink analysis of Amasra fine coal

Tab. 2. Analiza densymetryczna drobnouziarnionego węgla z Amasry

\begin{tabular}{|c|c|c|c|c|c|c|c|c|c|c|c|c|}
\hline \multirow{2}{*}{\multicolumn{3}{|c|}{$\begin{array}{l}\text { Specific } \\
\text { gravity }\end{array}$}} & \multicolumn{3}{|c|}{ Direct } & \multicolumn{3}{|c|}{ Cumulative floats } & \multicolumn{3}{|c|}{ Cumulative sinks } & \multirow{3}{*}{$\begin{array}{c}\mathbf{y}=\mathbf{a}_{0}+\mathbf{a}_{1} / \mathbf{2} \\
13.36\end{array}$} \\
\hline & & & \multirow{2}{*}{$\begin{array}{r}\text { Wt. } \\
\text { (\%) } \\
26.71 \\
\end{array}$} & \multirow{2}{*}{$\begin{array}{c}\begin{array}{c}\text { Ash } \\
(\%)\end{array} \\
4.95\end{array}$} & \multirow{2}{*}{$\begin{array}{c}\begin{array}{c}\text { Ash } \\
\text { content }\end{array} \\
132.32\end{array}$} & \multirow{2}{*}{\begin{tabular}{|c|}
$\begin{array}{c}\text { Wt. } \\
(\%)\end{array}$ \\
26.71 \\
\end{tabular}} & \multirow{2}{*}{$\begin{array}{c}\begin{array}{c}\text { Ash } \\
\text { content }\end{array} \\
132.32 \\
\end{array}$} & \multirow{2}{*}{$\begin{array}{l}\begin{array}{l}\text { Ash } \\
(\%)\end{array} \\
4.95\end{array}$} & \multirow{2}{*}{$\begin{array}{c}\begin{array}{c}\text { Wt. } \\
(\%)\end{array} \\
100.00\end{array}$} & \multirow{2}{*}{$\begin{array}{c}\begin{array}{c}\text { Ash } \\
\text { content }\end{array} \\
2478.34\end{array}$} & \multirow{2}{*}{$\begin{array}{c}\begin{array}{c}\text { Ash } \\
(\%)\end{array} \\
24.78\end{array}$} & \\
\hline Float & - & 1.30 & & & & & & & & & & \\
\hline 1.30 & - & 1.40 & 30.30 & 6.01 & 182.01 & 57.01 & 314.34 & 5.51 & 73.29 & 2346.02 & 32.01 & 41.86 \\
\hline 1.40 & - & 1.50 & 13.30 & 17.74 & 236.04 & 70.31 & 550.38 & 7.83 & 42.99 & 2164.00 & 50.34 & 63.66 \\
\hline 1.50 & - & 1.60 & 4.96 & 35.16 & 174.27 & 75.27 & 724.66 & 9.63 & 29.68 & 1927.96 & 64.95 & 72.79 \\
\hline 1.60 & - & 1.70 & 3.07 & 49.69 & 152.74 & 78.34 & 877.40 & 11.20 & 24.73 & 1753.68 & 70.92 & 76.81 \\
\hline 1.70 & 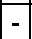 & 1.80 & 3.27 & 57.48 & 187.81 & 81.61 & 1065.21 & 13.05 & 21.65 & 1600.94 & 73.93 & 79.98 \\
\hline 1.80 & - & 1.90 & 7.35 & 66.53 & 488.81 & 88.96 & 1554.02 & 17.47 & 18.39 & 1413.13 & 76.86 & 85.28 \\
\hline Sink & $1-$ & 1.90 & 11.04 & 83.73 & 924.32 & 100.00 & 2478.34 & 24.78 & 11.04 & 924.32 & 83.73 & 87.13 \\
\hline \multicolumn{3}{|c|}{ Total } & 100.00 & 24.78 & 2478.34 & & & & & & & \\
\hline
\end{tabular}

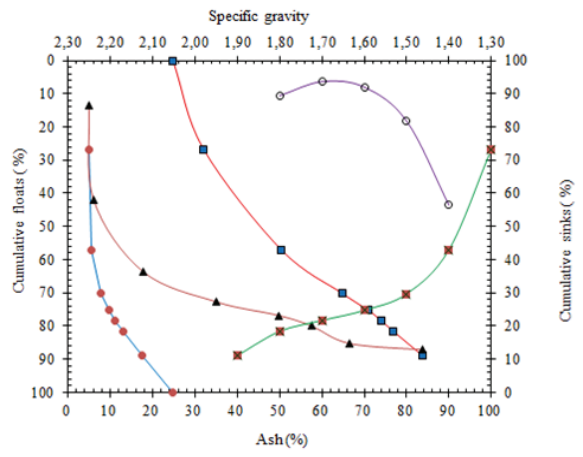

Fig. 2. Washability curves for Amasra fine coal

Rys. 2. Krzywe wzbogacalności drobnouziarnionego węgla z Amasry

Table 4 and Figure 4 show the float and sink analysis of the tailing. Total ash content of the tailing product was $70.56 \%$. There was no floated material at 1.30 specific gravity of, which signified that coal particles were collected in the clean coal product.

The cumulative ash content at 1.40 specific gravity was found to be $2.10 \%$ and total weight was $16.79 \%$. After the 1.80 specific gravity, weight of the waste product and its ash content increased rapidly. Weight of sink material at 1.90 specific gravity was $48.8 \%$ and its ash content was $84.19 \%$.

Partition curve is used for performance evaluation of any gravity concentration unit. Once the partition coefficient is plotted based on mean of its density range, the partition curve or Tromp curve (introduced by Tromp in 1937) is obtained (Gupta and Yan, 2018). Distribution curve for each test is plotted based on sink-float data of the overflow and underflow products. Normally, distribution curve is relatively dependent on the float and sink properties of the coal based on the particle size distribution as well as the type of separating unit. Data obtained from float and sink analysis on the raw coal, the clean coal and residue is used in following equation to determine the partition coefficients (Gupta and Yan, 2016):

Partition Coefficient $=\frac{\text { (mass of coal reporting in any SG range) }}{(\text { mass of feed coal present in that SG range })} \times 100$

The Tromp partition curve was plotted to evaluate the knelson concentrator based on the float and sink analysis data of the clean coal and waste products from Amasra fine coal. Table 5 and Figure 5 show the results.
The two important performance factors were measured from Tromp curve; cut density $\left(\mathrm{SG}_{50}\right)$ and Ecart probable error (Ep). The specific gravity cut point, $\mathrm{SG}_{50}$, refers to the specific gravity of those particles in the feed that has a $50 \%$ possibility of moving to the overflow or the underflow in separator (Zhang, 2008). Conventional fine coal cleaning technologies such as single-pass spiral concentrator circuits typically provide relatively high separation density values of 1.8 and greater (Osborne, 1988; Honaker and Ozsever, 2000). In this study, SG50 was found to be 1.72 .

The Ecart probable error, Ep () was used as the efficiency criterion. Ep refers to the deviation of actual curve from the ideal curve. It is estimated from the following equation (Zhang, 2008)

$\mathrm{E}_{\mathrm{p}}=\left(\mathrm{SG}_{25}-\mathrm{SG}_{75}\right) / 2$

Where $\mathrm{SG}_{25}$ and $\mathrm{SG}_{75}$ are $25 \%$ and $75 \%$ of feed material representing to the clean coal. Probable error value should be zero for ideal separation and higher probable error values signify poorer separations (Rao, 2000). Probable error values in the range of 0.15 to 0.20 indicates moderate separation efficiency compared to the values realized from the process cleaning the coarse fractions with values of 0.05 and lower (Osborne, 1988; Honaker and Ozsever, 2000). A low Ep (0.02) indicates a very precise separation and a high Ep $(0.20)$ indicates a very imprecise separation (URL 1). In this study, Ep was calculated for Amasra fine coal using following formula 2 : 
Tab. 3. Float and sink test results of the clean coal product

Tab. 3. Wyniki testów densymetrycznych dla czystego węgla

\begin{tabular}{|c|c|c|c|c|c|c|c|}
\hline \multicolumn{2}{|c|}{$\begin{array}{c}\text { Specific gravity } \\
\text { range }\end{array}$} & $\begin{array}{c}\text { Mean Sp. } \\
\text { gr. }\end{array}$ & Weight & Ash & $\begin{array}{c}\text { Cumulative } \\
\text { weight }\end{array}$ & Cumulative ash \\
\hline \multicolumn{2}{|c|}{} & & $\mathbf{( \% )}$ & $\mathbf{( \% )}$ & $\mathbf{( \% )}$ & $\mathbf{( \% )}$ \\
\hline Float & - & 1.30 & 1.25 & 33.67 & 3.93 & 33.67 & 3.93 \\
\hline 1.30 & - & 1.40 & 1.35 & 37.65 & 5.85 & 71.32 & 4.94 \\
\hline 1.40 & - & 1.50 & 1.45 & 15.78 & 17.17 & 87.10 & 7.16 \\
\hline 1.50 & - & 1.60 & 1.55 & 5.31 & 34.56 & 92.41 & 8.73 \\
\hline 1.60 & - & 1.70 & 1.65 & 2.65 & 46.69 & 95.06 & 9.79 \\
\hline 1.70 & - & 1.80 & 1.75 & 1.80 & 55.93 & 96.86 & 10.65 \\
\hline 1.80 & - & 1.90 & 1.85 & 1.94 & 64.45 & 98.80 & 11.71 \\
\hline Sink & - & 1.90 & 2.25 & 1.20 & 78.89 & 100.00 & 12.51 \\
\hline Total & & & & $\mathbf{1 0 0 . 0 0}$ & $\mathbf{1 2 . 5 1}$ & & \\
\hline
\end{tabular}

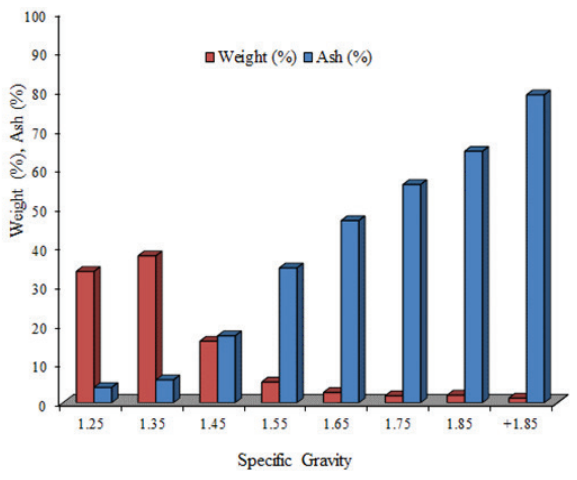

Fig. 3. Weight (\%) and ash content (\%) of clean coal according to float and sink analysis Rys. 3. Zawartość masowa (\%) i popiołu (\%) w czystym węglu według analizy densymetrycznej

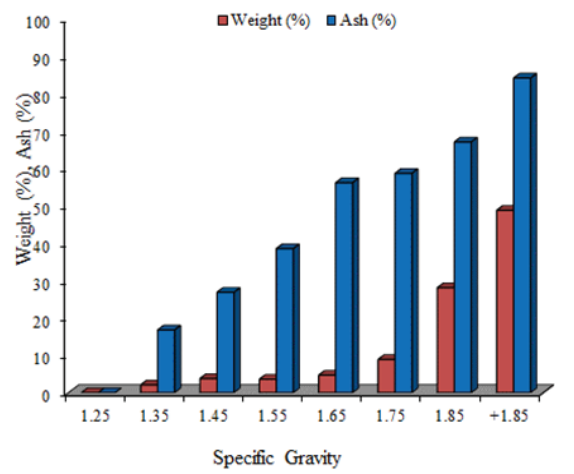

Fig. 4. Weight (\%) and ash content (\%) of the tailing according to float and sink analysis Rys. 4. Zawartość masowa (\%) i popiołu (\%) w odpadzie według analizy densymetrycznej

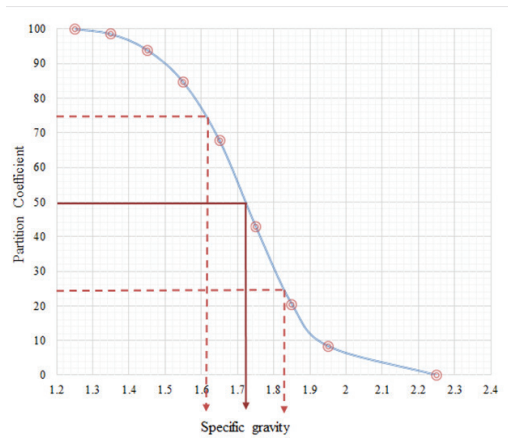

Fig. 5. Tromp partition curve Rys. 5. Krzywa rozdziału Trompa 
Tab. 4. Float and sink test results of the tailing

Tab. 4. Wyniki testów densymetrycznych dla odpadu

\begin{tabular}{|c|c|c|c|c|c|c|c|}
\hline \multicolumn{2}{|c|}{$\begin{array}{c}\text { Specific gravity } \\
\text { range }\end{array}$} & $\begin{array}{c}\text { Mean Sp. } \\
\text { gr. }\end{array}$ & Weight & Ash & Cumulative weight & Cumulative ash \\
\hline \multicolumn{2}{|c|}{} & & $(\%)$ & $\mathbf{( \% )}$ & $\mathbf{( \% )}$ & $\mathbf{( \% )}$ \\
\hline Float & - & 1.30 & 1.25 & 0 & 0.00 & 0.00 & 0.00 \\
\hline 1.30 & - & 1.40 & 1.35 & 2.1 & 16.79 & 2.10 & 16.79 \\
\hline 1.40 & - & 1.50 & 1.45 & 3.8 & 26.87 & 5.90 & 23.28 \\
\hline 1.50 & - & 1.60 & 1.55 & 3.6 & 38.56 & 9.50 & 29.07 \\
\hline 1.60 & - & 1.70 & 1.65 & 4.7 & 56.19 & 14.20 & 38.05 \\
\hline 1.70 & - & 1.80 & 1.75 & 8.9 & 58.68 & 23.10 & 46.00 \\
\hline 1.80 & - & 1.90 & 1.85 & 28.1 & 67.08 & 51.20 & 57.57 \\
\hline Sink & - & 1.90 & 2.25 & 48.8 & 84.19 & 100.00 & 70.56 \\
\hline Total & & & & $\mathbf{1 0 0 . 0 0}$ & $\mathbf{7 0 . 5 6}$ & & \\
\hline
\end{tabular}

Tab. 5. Float and sink analysis results of the feed material

Tab. 5. Wyniki analizy densymetrycznej dla nadawy

\begin{tabular}{|c|c|c|c|c|c|c|c|c|c|}
\hline \multicolumn{2}{|c|}{$\begin{array}{c}\text { Specific gravity } \\
\text { range }\end{array}$} & $\begin{array}{c}\text { Mean } \\
\text { Sp. gr. }\end{array}$ & $\begin{array}{c}\text { Clean } \\
\text { coal }\end{array}$ & Tailing & $\begin{array}{c}\text { Clean } \\
\text { coal\% }\end{array}$ & Tailing \% & Calculated & $\begin{array}{c}\text { Partition C for } \\
\text { clean coal }\end{array}$ \\
\hline \multicolumn{2}{|c|}{} & & $\mathbf{( W t . \% )}$ & $\mathbf{( W t . \% )}$ & B x0.7886 & D x 0.2114 & E+F & \\
\hline \multicolumn{2}{|c|}{ A } & B & C & D & E & F & G & H \\
\hline Float & - & 1.30 & 1.25 & 33.67 & 0.00 & 26.55 & 0.00 & 26.55 & 100.00 \\
\hline 1.30 & - & 1.40 & 1.35 & 37.65 & 2.10 & 29.69 & 0.44 & 30.13 & 98.53 \\
\hline 1.40 & - & 1.50 & 1.45 & 15.78 & 3.80 & 12.44 & 0.80 & 13.25 & 93.94 \\
\hline 1.50 & - & 1.60 & 1.55 & 5.31 & 3.60 & 4.19 & 0.76 & 4.95 & 84.62 \\
\hline 1.60 & - & 1.70 & 1.65 & 2.65 & 4.70 & 2.09 & 0.99 & 3.08 & 67.78 \\
\hline 1.70 & - & 1.80 & 1.75 & 1.80 & 8.90 & 1.42 & 1.88 & 3.30 & 43.00 \\
\hline 1.80 & - & 1.90 & 1.85 & 1.94 & 28.10 & 1.53 & 5.94 & 7.47 & 20.48 \\
\hline Sink & - & 1.90 & 2.25 & 1.20 & 48.80 & 0.95 & 10.32 & 11.26 & 8.40 \\
\hline Total & & & $\mathbf{1 0 0 . 0 0}$ & $\mathbf{1 0 0 . 0 0}$ & $\mathbf{7 8 . 8 6}$ & $\mathbf{2 1 . 1 4}$ & & \\
\hline
\end{tabular}

$\operatorname{Ep} \frac{(1.84-1.62)}{2}=0.11$

\section{Conclusion}

Modern gravity techniques have been used effectively in recent years for treating fine and ultrafine particles. In this study, Knelson concentrator developed to make use of centrif- ugal force was used for cleaning of Amasra fine coal. Several tests were performed in optimal operating conditions after that operating cut point and efficiency of the separation were determined based on the results of the float and sink analysis. The Tromp partition curve indicated that separation performance of Knelson concentrator was effective for $-1+0.150 \mathrm{~mm}$ Amasra fine coal.

\section{Literatura - References}

1. BANISI, S. An investigation of the behavior of gold in grinding circuits, (Master's Thesis). Mining and Metallurgical Engineering, Department McGill University, Montreal, Canada. 1990.

2. BURT, R. O. Gravity concentration of ultrafines- A literature review of centrifugal concentrating devices. MDA Report. 1992.

3. GUPTA, A.; YAN, D.S. Mineral Processing Design and Operations. Second Ed., Elsevier, USA.2016.

4. HONAKER R.Q.; DAS A.; NOMBE M. Improving the separation efficiency of the knelson concentrator using air injection. Coal Preparation. 2005, 25 (2), 99-116. 
5. HONAKER, R. Q.; FORREST, W.R. Advances in gravity concentration. Society for Mining, Metallurgy and Exploration, Inc. (SME), Colorado, USA. 2003, ISBN 0-87335-227-0.

6. HONAKER, R.Q.; OZSEVER, A.V. Innovations in fine coal density separations. Advances in Gravity Concentration. Honaker and Forrest (Ed) Society for Mining and Exploration, Colorado, USA, 2000, 125-140. ISBN 0-87335-227-0.

7. KAWATRA, S.K.; EISELE, T.C. Coal desulphurization, high-efficiency preparation methods. First ed., Taylor\&Francis Inc., New York. 2001, ISBN 90-5699-696-7.

8. LAPLANTE, A.R. A comparison of two centrifugal concentrators. Annual Canadian Mineral Processors' Conference, Ottawa, ON, Canada, 1993.

9. LUTTRELL, G.H.; HONAKER, R. Q.; PHILLIPS, D. I. Enhanced gravity separators: New alternatives for fine coal cleaning. 12th International Coal Preparation Conference, Lexington, KT, 1995, 281-292.

10. LUTTRELL, G.H.; BARFEE, C.J.; STANLEY, FL. Optimum outpoints for heavy medium separations, Honaker and Forrest (Ed) Society for Mining and Exploration, Colorado, USA, 2000, 81-91. ISBN 0-87335-227-0

11. MAJUMDER, A.K.; BARNWALL J.P. Modeling of enhanced gravity concentrators- present status. Mineral Processing \& Extractive Metall. Rev., 2006, 27, 61-86.

12. MAJUMDER, A.K.; BARNWAL, J.P. New possibilities in fine coal beneficiation techniques. The Institution of Engineers (India)-Mining, 2008, 89, 3-8.

13. MCLEAVY, M.; KLEIN, B.; GREWAL, I. Knelson continuous variable discharge concentrator: Analysis of operating variables. International Heavy Minerals Conference, Fremantle, WA, 18 - 19 June, 2001, 119-125.

14. MEYER, E.J.; CRAIG, I. K. Development of a steady-state partition curve from a dense medium cyclone dynamic model in coal beneficiation. Proceedings of the 18th World Congress. The International Federation of Automatic Control Milano (Italy) August 28 - September 2, 2011.

15. ONEY, O.; SAMANLI, S.; NIEDOBA, T.; PIĘTA, P.; SUROWIAK, A. Determination of the important operating variables on cleaning fine coal by knelson concentrator and evaluation of the performance through upgrading curves. International Journal of Coal Preparation and Utilization, (article in press), http://dx.doi.org/10.1080/1939 2699.2017.1397641

16. OSBORNE, D.G. Coal Preparation Technology, Graham and Trotman, Norwell, MA. 1988. ISBN 1853330922.

17. RAO, T.C. Dense medium cyclone, http://eprints.nmlindia.org/2906/1/127-140.PDF, 2000, (Accessed date: 10.11.2019).

18. TAO, Y.J.; LUO, Z.F.; ZHAO, Y.M.; TAO, D. Experimental research on desulphurization of fine coal using an enhanced centrifugal gravity separator. Journal of China University of Mining \& Technology, 2006, 16, 399-403.

19. URL 1, http://www.albrechts.com/mike/articles/Introduction\%20to\%20Coal\%20Preparation.pdf.

20. USLU, T.; SAHINOGLU, E.; YAVUZ, M. Desulphurization and deashing of oxidized fine coal by knelson concentrator. Fuel Processing Technology, 2012, 101, 94-100.

21. ZHANG, B. Performance optimization of a compound spiral for fine and ultrafine coal cleaning. Master Thesis. Southern Illinois University. 2008.

22. ZHANG, B.; BRODZIK, P.; MOHANTY, M.K. Improving fine coal cleaning performance by high-efficiency particle size classification. International Journal of Coal Preparation and Utilization, 2014, 34, 145-156.

\footnotetext{
Określenie jakości rozdzialu w separatorze Knelson

Celem tego badania było określenie jakości rozdziału materiału $w$ separatorze Knelson dla drobnouziarnionego węgla z Zonguldak $(-1+0,15 \mathrm{~mm})$. Doświadczenia przeprowadzono w separatorze typu Knelson przy zastosowaniu optymalnych wartości parametrów, które otrzymano w poprzednich badaniach, tj. przeplyw wody 3,14l/min, prędkość misy 459 rpm, zawartość fazy stałej 23,87\% oraz przeplyw nadawy 1,50 l/min. Przeprowadzono serię testów przy optymalnych parametrach testowych w otrzymania odpowiedniej ilości dla analizy densymetrycznej. Czysty wegiel oraz odpady poddano takiej analizie, na podstawie której wygenerowano krzywa rozdziału dla procesu czyszczenia. Ziarno podziałowe rozdziału otrzymano przy gęstości właściwej 1,72 [g/cm $\left.{ }^{3}\right]$. Wartość rozproszenia prawdopodobnego (Ep), która oznacza skuteczność procesu została określona jako 0,11. Wyniki te wskazaty, że separator Knelson jest bardzo efektywny przy rozdziale drobnouziarnionego wegla.
}

Słowa klucze: separator Knelson, drobnouziarniony węgiel, jakość rozdziału, analiza densymetryczna, krzywa rozdziału 